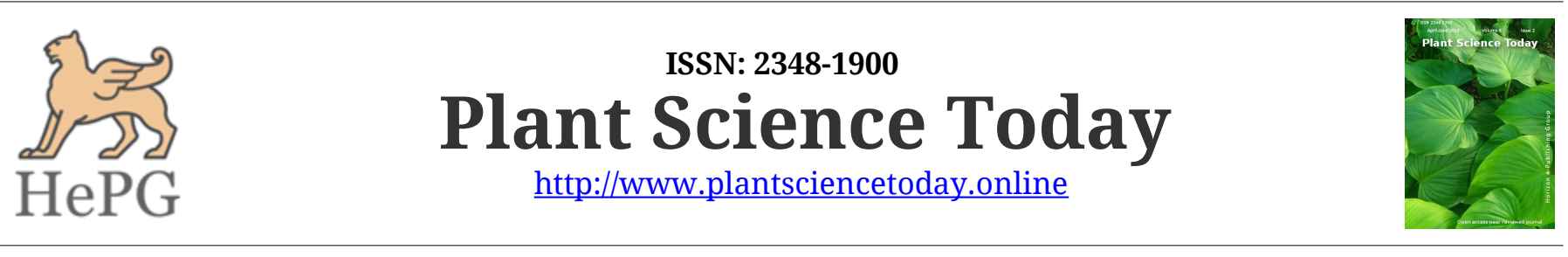

OPEN ACCESS

Research Article

\title{
The genus Dendrobium Sw. (Orchidaceae) in Tripura, India
}

\author{
Biswajit Baishnab* \& Badal Kumar Datta \\ Plant Taxonomy \& Biodiversity Laboratory, Department of Botany, Tripura University, Suryamaninagar 799022, India
}

\section{Article history}

Received: 26 February 2019

Accepted: 04 April 2019

Published: 09 May 2019

\section{Publisher}

Horizon e-Publishing Group

\section{*Correspondence}

Biswajit Baishnab

\biswajit.baishnab540@gmail.com

\begin{abstract}
Tripura is a part of Indo-Burma biodiversity hotspot and is rich in orchid diversity. The present paper deals with 10 species of Dendrobium recorded from Tripura during the field survey in 2016-2018. This paper deals with three new additions of Dendrobium species i.e., Dendrobium aphyllum, Dendrobium capillipes and Dendrobium formosum to Tripura.
\end{abstract}

Keywords: Orchidaceae; Dendrobium; diversity; distribution; Tripura

Citation: Baishnab B, Datta BK. The genus Dendrobium Sw. (Orchidaceae) in Tripura, India. Plant Science Today 2019;6(2):190-200. https://doi.org/10.14719/pst.2019.6.2.516

\begin{abstract}
Copyright: (c) Baishnab \& Datta (2019). This is an open-access article distributed under the terms of the Creative Commons Attribution License, which permits unrestricted use, distribution, and reproduction in any medium, provided the original author and source are credited (https://creativecommons.org/licenses/by/4.0/).
\end{abstract}

Indexing: Plant Science Today is covered by Scopus, CAS, AGRIS, CABI, Google Scholar, etc. Full list at http://www.plantsciencetoday.online

\section{Introduction}

The genus Dendrobium Sw. (nom.cons.) exhibiting amazing species diversity with variable size, shape, structure, colour and fragrance is distributed throughout the world from tropical \& warm Asia to Australia and Pacific and comprises c. 1500 species $(1,2)$. The genus name Dendrobium is derived from two Greek words dendron and bios which means tree and life, respectively. Actually Dendrobium means that the orchids are living on another tree i.e., epiphytes. Dendrobiums falls under sympodial group of orchids with pseudobulbs, or "canes" which are modified form of orchid stem subject to reserve food and water. Maximum of their habit is to creep over the substratum i.e. tree trunks or branch. At the upper portion of a branch or stem there are at least six leaves arranged in alternate or opposite pattern and flowers are arranged on single rachis. They show morphological variations in vegetative (pseudobulbs or canes and leaves and their shape and size) as well as in reproductive parts (flowers; shape, size, colours, fragrant, etc). Four to twelve flowers bloom per inflorescence, with two to five $\mathrm{cm}$ in average size. Flowers open with variety of attractive colour or its combination such as white, orange, yellow, pink, green, purple, cream and last for 15-25 days. Like other orchids, Dendrobium also has flowers with six perianth segments (three petals and three sepals) of which one is labellum. This lip has large stage like space with various colours and shape to attract pollinators. Dendrobium is the second largest genus of orchid and is represented by 91 species \& 4 varieties and 103 species respectively in India $(3,4)$. In north-east India there are about 77 species (4). Several field visits under DBT orchid project from Tripura University was conducted to Jampui Hill of North Tripura State and Amarpur and Dumbur of Gomati district for the collection and documentation of endemic and threatened orchid species and also for conservation of the same in the 
shade house at Tripura University. Prior to this survey, however, the genus Dendrobium Sw. was represented by 7 species, 6 species i.e., Dendrobium angulatum Lindl., Dendrobium fimbriatum Hook., Dendrobium salaccense (Blume) Lindl., Dendrobium transparens Wall. ex Lindl., Dendrobium chrysotoxum Lindl., Dendrobium lindleyi Steud. in the flora of Tripura by Deb (5) and another species Dendrobium densiflorum Lindl. included by the authors (6). Present paper deals with three more new additions of Dendrobium spp. to the flora i.e., Dendrobium aphyllum (Roxb.) C.E.C. Fisch., Dendrobium capillipes Rchb.f. and Dendrobium formosum Roxb. ex Lindl.

Tripura is one of the most biodiversity rich states of north-east India. The area of Tripura is $10491 \mathrm{~km}^{2}$ of which about $60.02 \%$ that is $6294 \mathrm{~km}^{2}$ is under forest cover. The geographical location of Tripura is $22^{\circ} 56^{\prime} \mathrm{N}$ to $24^{\circ} 32^{\prime} \mathrm{N}$, and $91^{\circ} 09^{\prime} \mathrm{E}$ to $92^{\circ} 20^{\prime} \mathrm{E}$. From north to south its longest extent measures is about $184 \mathrm{~km}(114 \mathrm{mi})$ and in east to west $113 \mathrm{~km}(70 \mathrm{mi})$. This small state consists of eight districts, namely Dhalai, Sipahijala, Khowai, Gomati, North Tripura, South Tripura, West Tripura, and Unakoti. Our investigation mainly carried out in Jampui hill range of north Tripura and Amarpur, Dumbur (Tirthamukh) of Gomati district. The Jampui ranges enlarge from north to south and share border with Mizoram in the east. The highest peak of the state, Betlingchip is located in this range. The average altitude of the range is about 1000 metres. Climate of this region is typically tropical dry and wet climate with a high level of humidity and heavy rainfall. The rainy and moist environment of the state supports diverse flora including rich orchid diversity. The maximum nos. of Dendrobium species are found in Jampui range of North Tripura district due to its high altitude and low temperature. Out of three new records, two orchids, $D$. formosum and Dendrobium capillipes were found in Vanghmun $\left(23^{\circ} 58^{\prime} 36.0^{\prime \prime} \mathrm{N}, 92^{\circ} 16^{\prime} 44.5^{\prime \prime E}\right)$ at an elevation of 569 meters and another Dendrobium aphyllum at Maharani $\left(23^{\circ} 28^{\prime} 41.7^{\prime \prime} \mathrm{N}, 9^{\circ} 39^{\prime} 16.2^{\prime \prime E}\right)$ of Gomati, at an elevation of $41 \mathrm{mt}$.

\section{Materials and Methods}

The rigorous field research was carried out from 2016-2018 in all the seasons of the year covering several reserve forests and hilly areas of Tripura. Harvested orchid specimens were carried to the department through a polythene bag and flowers were preserved in plastic container with FAA solution from the field and made into standard mounted herbarium sheets following the procedure of Jain and Rao (7). Photographs and other geographical and ecological data were also collected from the field. After two years of study the author has found 10 species of Dendrobium genus of which three were considered as new additions and all the 10 species are maintained in orchid house of the Botany Department of Tripura University. After the taxonomical workout with suitable description the orchids were identified and nomenclature checked with the help of the apposite literatures of $(5,8,9,10,11,12,13,14,15)$ and specimen verification was done in the herbarium of the Department of Botany, Tripura University. After perusal of the literature, it was noticed that three species viz., Dendrobium aphyllum, Dendrobium formosum and Dendrobium capillipes formed new records to the flora of Tripura State. The correct nomenclature, diagnostic characters, phenology, ecology and distribution of the species are highlighted in brief along with a key for identification. The conservation status of the orchid species are reported by checking the IUCN red-list website (16).

\section{Results}

\section{Taxonomic treatment}

Dendrobium Sw., Nova Acta Regiae Soc. Sci. Upsal. 6: 82 (1799), nom. cons.

Epiphytes, herbs with erect or pendulous, tough or fleshy, short or elongate pseudobulbous stems. Leaves sessile, sheathing at the base, one or two at the top of the pseudobulb or many and arranged alternately along the stem, linear to lanceolate, oblong, or ovate, apex usually 2-lobed or notched. Inflorescence axillary or from the bracts at the apex of the pseudobulb, racemose with 1- many flower, erect or pendulous. Sepals subequal, free; lateral sepals adnate to the foot of the column to form a mentum. Petals similar, free; lip sessile, adnate to column foot, entire to distinctly 3-lobed, margin entire to fimbriate, base attached to lateral sepals to form spur and often narrowly clawed. Column free, short with long foot, anterior part with a knob, occupied by the stigma, side arm short; foot short or long, sometimes absent, hollowed on the front, base necteriferous; rostellum small diagonally lamellate. Anthers 2 celled; stalk short, subulate or filiform; pollinia 4 in packed pairs, caudicles or stipes absent. Capsules ovoid or subovoid.

Key to the species for identification of Dendrobium species in Tripura

1a. Stem without pseudobulbs

1b. Stem with pseudobulbs.

2a. Stem with 2-3 internodes, much swollen, fusiform tuberous

D. angulatum (DANG)

2b. Stem cane-like, pendulous, 5-15 internodes, 20-150 $\mathrm{cm}$ long, without tuberous swelling, many flowers....................................... D. aphyllum (DAPH)

3a. Stems fusiform, $8-15 \mathrm{~cm}$, fleshy, with obtuse longitudinal ridges and few internodes, inflorescence from old leafless stems, flowers yellow.....

D. capillipes (DCPS) 


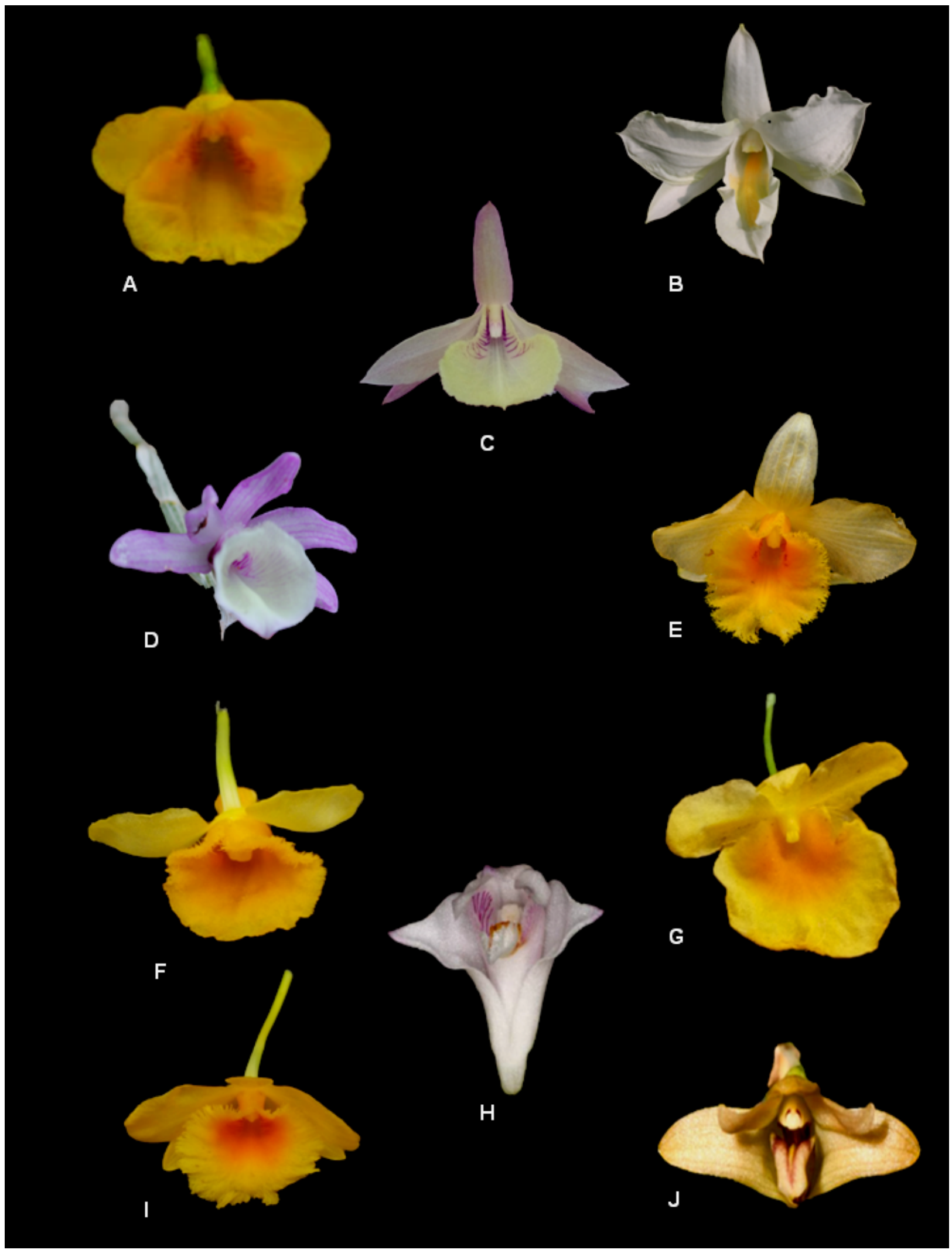

Fig. 1: Figures of flowers intacts. A. D. capillipes; B. D. formosum; C. D. aphyllum; D. D. transparens; E. D. fimbriatum; F. D. densiflorum; G. D. lindleyi; H. D. angulatum; I. D. chrysotoxum; J. D. salascence

3b. Stems thick and pointed upwards, inflated at the base, covered by leaf sheath, 8 to $15 \mathrm{~cm}$ long and 1 to 2 $\mathrm{cm}$ in cross segment, flowers odorous, 5-9 cm, white with yellowish-blotch on lip ..... D. formosum (DFMS)

4a. Lip with fringed at the margin

$4 \mathrm{~b}$. Lip without fringes at the margin 5a. Lip deeply fringed, flowers about $5 \mathrm{~cm}$ across, orange yellow.

D. fimbriatum (DFMB)

5b. lip rather long ciliate, lip golden yellow, more sparsely so toward edges; floral bracts to $2.4 \mathrm{~cm}$. Inflorescence subterminal, pendulous, peduncle with 2-4 sheaths at base; rachis 6-16 cm; densely many flowered..... 


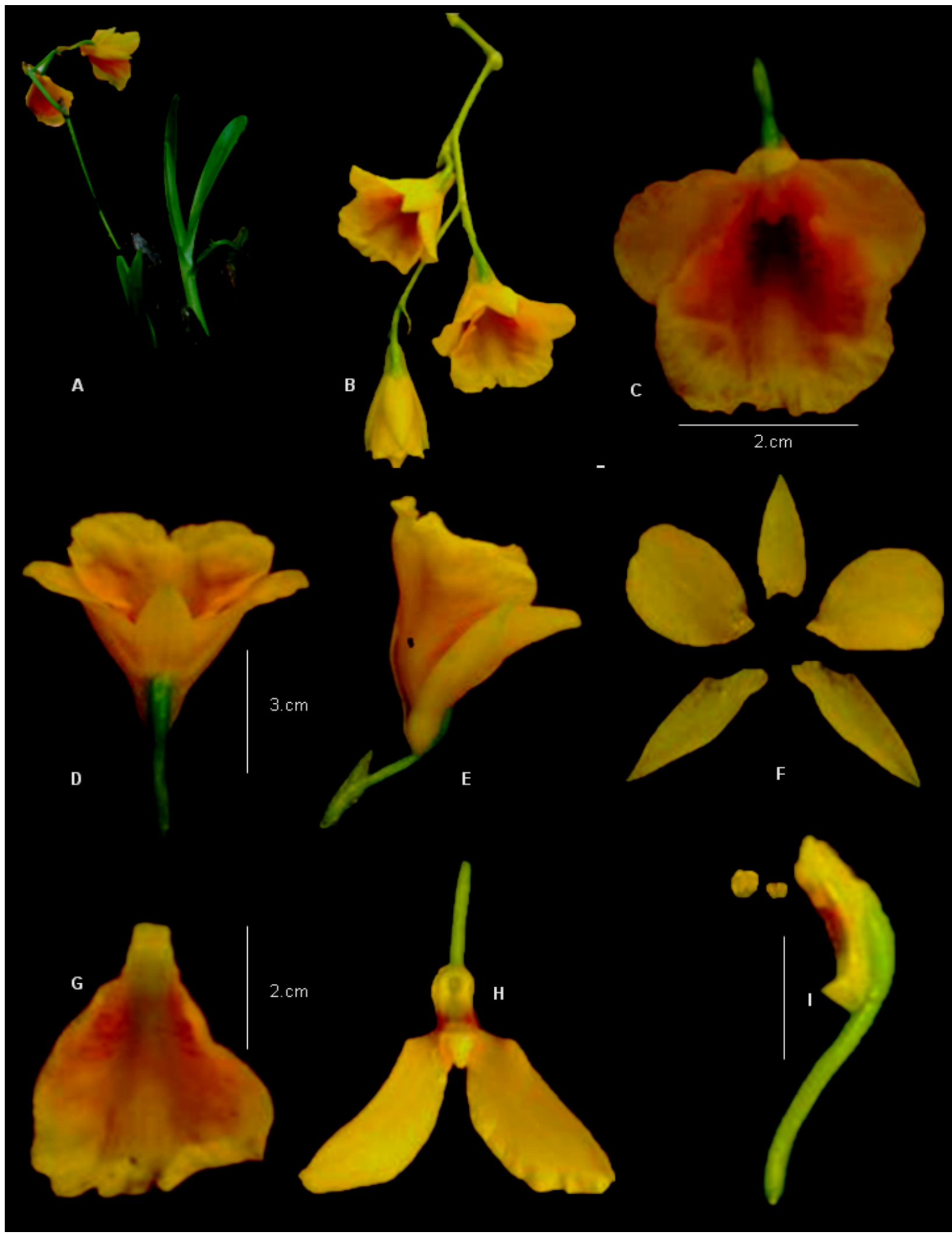

Fig. 2: Dendrobium capillipes. A. Whole plant; B. Inflorescence; C. Flower (Front view); D. Flower dorsal view; E. Flower with bract; F. Sepal \& Petal; G. Lip; H. Column with Sepal; I. Column with Ovary.

6a. Lip pubescent, recurved at the margin with one or two broad purple blotches; leaves linear-lanceolate, tip without notch.

D. transparens (DTRS)

6b. Lip neither pubescent nor recurved at the margin; golden yellow with purple on the lip; leaves unequally two fid at the tip.

D. salascence (DSLS) 7a. Pseudobulbs fusiform; leaves solitary, oblong, notched at the top D. lindleyi (DLYI)

7b. Pseudobulbs subcylindric with several leaves, leaves oblong to lanceolate; lip 2 fid; flowers yellow; lip orange streaked or blotched with red...D. chrysotoxum (DCHY) 


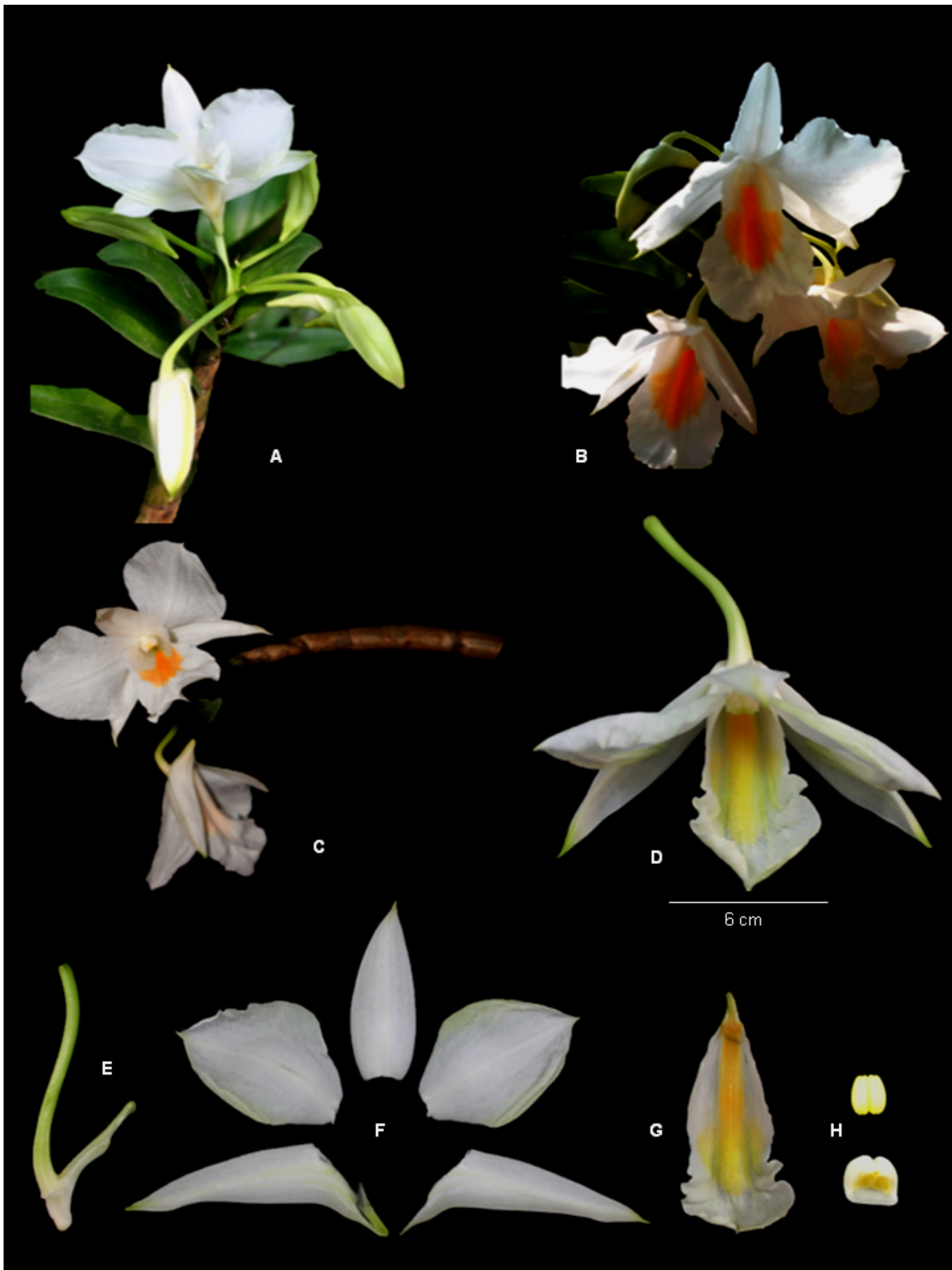

Fig. 3: Dendrobium formosum. A. Whole Plant; B. Inflorescence; C. Flower Intact with stem; D. Intact Flower; E. Column and Ovary; F. Sepal \& Petal; G. Lip; H. Pollinia with Cap.

1. Dendrobium angulatum Lindl., Gen. Sp. Orchid. Pl.: 88. 1830. Dendrobium podagraria Hook.f., Fl. Brit. India 5: 728 (1890), nom. illeg.; Kataki \& Panigrahi, Bull. Bot. Surv. India 5:243. 1963.

Epiphyte, stem branched with 2-3 internodes above the base much swollen into a fusiform, tuberous section, elsewhere slender rigid. Leaves 4-5 cm long, 3-12 in number, linear to oblong, widely spaced $4-5 \mathrm{~cm}$ long, linear oblong, obtuse or emarginated. Flower comes out from the node apex, rachis short. Single flower, diagonally $1.5 \mathrm{~cm}$, yellow with white reflect. Dorsal sepals lanceolate, petals are narrowly oblong-lanceolate; 3-nerved, 
mentum incurved longer than the lateral sepals. Lip white with pink veins (Fig. 1)

Distribution: India (Assam), Bangladesh, Burma, south-western Thailand and Vietnam.

Phenology: Flowering and fruiting was observed from April - June.

Habitat and Ecology: Epiphytes on tree trunks at shady moist, mixed deciduous forest of Jampui range at elevation of 525 to $650 \mathrm{~m}$.

Specimen Examined: India, Tripura, North district, Jampui hill, $\pm 578 \mathrm{~m}, 23^{\circ} 59^{\prime} 32.6^{\prime \prime N}$, 92¹6'34.9"E, 08-4-2017 Datta \& Baishnab, 1974 (TUH).

2. Dendrobium chrysotoxum Lindl. in. Bot. Reg.1847:t.36.1847; Hook.f., Fl. Brit. India 5: 750.1890 .

Epiphyte, pseudobulbs clavate, erect, fusiform, 6$30 \mathrm{~cm}$, with many oblong-lanceolate. Leaves $2-5$, at stem apex, bifid at the tip, $16 \times 2-3.5 \mathrm{~cm}$ in size, acute. Flower golden yellow, about $5 \mathrm{~cm}$ across, many, in loose lateral slender decurved racemes. Lip orbicular, pubescent, orange streaked or blotched with red, margin pectinately fringed; petals twice as large as the oblong sepals; mentum rounded. Petals oblanceolate, margin minutely dentate, apex rounded; lip nearly reniformorbicular, margin undulate, apex shallowly bilobed; Column $5 \mathrm{~mm}$; anther cap tower-shaped (Fig. 1).

Distribution: China, NE India, Laos, Myanmar, Thailand, Vietnam.

Phenology: Flowering and fruiting occurs in March-June.

Habitat and Ecology: Epiphyte on tree trunk at shade patches of Jampui hill.

Specimen Examined: India, Tripura, North district, Jampui hill, Sabual, $\pm 794 \mathrm{~m}, 23^{\circ} 49^{\prime} 58.0^{\prime \prime N}$, 92¹5'30.1"E, 24-4-2018, Datta \& Baishnab, 1975 (TUH).

3. Dendrobium densiflorum Lindl. in N.Wallich, Pl. Asiat. Rar. 1: 34. 1830; Hook. f., Fl. Brit. India 5: 748. 1890.

Stem tetrangular, mid portion inflamed but narrow at the base and apex, 25-40 cm length and $2 \mathrm{~cm}$ in diameter. Leaves 3 or 4 from shoot apex, lanceolate, $8-15 \times 2.5-6 \mathrm{~cm}$, fibrous, apex acute. Subterminal inflorescence with soft peduncle, at base covered with 2-4 sheaths, pendulous; rachis 6$16 \mathrm{~cm}$ long with many flowers. Flowers $3-4 \mathrm{~cm}$ across, pedicel and ovary 2-2.5 cm long, light green. Sepals and petals pale yellow, lip golden yellow, margin broad at apex and slightly fimbriate, column occurs anther cap at anterior side and orange-yellow in colour (Fig. 1).
Distribution: China, Bhutan, NE India, Myanmar, Nepal, northern Thailand.

Phenology: Flowering and fruiting occurs in April - June.

Habitat and Ecology: cold to warm medium size epiphyte grows on tree trunk in dense mixed forest, under low sunlight.

Specimen Examined: India, Tripura, North district, Jampui hill, $\pm 826 \mathrm{~m}, \quad 23^{\circ} 49^{\prime} 58.0^{\prime \prime N}$, 92¹5'30.1"E,10-4-2018, Datta and Baishnab, 1985 (TUH).

4. Dendrobium fimbriatum Hook., Exot. Fl. 1: t. 71. 1823; Hook.f. Fl.Brit.Ind.5:745.1890.

Epiphyte, swollen at the base, stiff, pendulous, 75-150 cm long, unbranched with many nodes and internodes. Leaves many up to $5 \mathrm{~cm}$ long, lanceolate, acuminate, sheathed at base. Racemose inflorescences, raceme from the leafy stem 15-20 cm long with 8-12 flowers each. Flower orange yellow, about $5 \mathrm{~cm}$ across. Sepals and petals subequal and golden yellow in colour. Dorsal sepal oblong, lateral sepals ovatelanceolate. Petals oblong-elliptic. Mentum short. Lip orbicular, yellow, with a truncate base and fringed at the margin. Column $2 \mathrm{~mm}$ (Fig. 1).

Distribution: India, Nepal, Bhutan, Burma, China, Thailand, Vietnam.

Phenology: Flowering and fruiting were observed from March-May.

Habitat and Ecology: This species is a medium to large sized, warm to cold growing epiphyte in shady places on tree trunks of Bombax ceiba, Mangifera indica and Ficus sps at elevation ranges from 510 to $750 \mathrm{~m}$ of Jampui ranges.

Specimen Examined: India, Tripura, North district, Jampui hill, $\pm 41 \mathrm{~m}, 23^{\circ} 55^{\prime} 49.8^{\prime \prime} \mathrm{N}$, 92 16'44.7"E, 28-3-2017, Datta and Baishnab, 1962 (TUH).

5. Dendrobium lindleyi Steud., Nomencl. Bot., ed. 2, 1: 490. 1840. P.F. Hunt \& Summerh., Kew Bull. 20: 55. 1966. Dendrobium aggregatum Roxb. Fl. Ind. (Ed. Carey) 3: 477. 1832 non Kunth, 1815; Hook. f., Fl. Brit. India 5:749. 1890.

Epiphytes with fusiform pseudobulbs, ovoidcylindric, green and become light yellow in dry condition, white thin sheath at the base. Leaves solitary, oblong, notched at the tip, $3-7 \times 0.6-3 \mathrm{~cm}$. Flowers in a drooping raceme from the axil of a lateral scale at the top of the stem with 6-10 flowers. Flower $3.75 \mathrm{~cm}$ across, orange in colour, bracts tiny in triangular shape, not more than 2 $\mathrm{mm}$. Petals much broader than the sepals, cuneate at the base. Sepals are almost similar, mentum subglobose. Petals elliptic and openly curved. Lip 


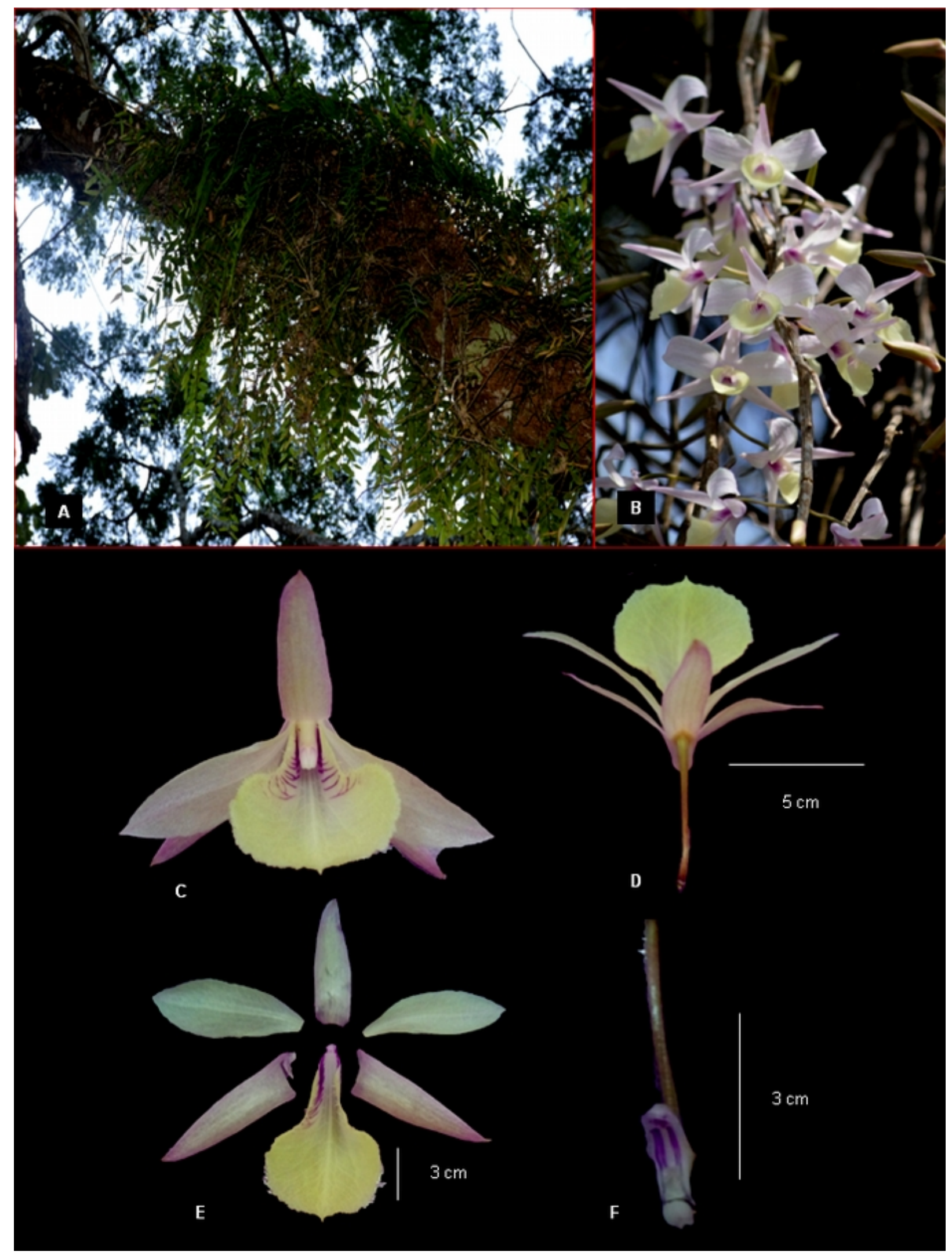

Fig. 4: Dendrobium aphyllum. A. Habitat; B. Leafless Cane with Inflorescence; C. Intact Flower; D. Dorsal View of Flower; E. Dissected Flower (Sepal\& Petal); F. Column with Ovary.

shortly clawed; disk concave, pubescent, column short and $4 \mathrm{~mm}$ (Fig. 1).

Distribution: India, north east India, Bangladesh, Srilanka, Myanmar, Thailand, China.
Phenology: Flowering and fruiting occurs in March-May.

Habitat and Ecology: It is a miniature to small sized, hot to cool growing epiphyte on tree trunk of Artocarpus heterophyllus and Albizia saman in full 
Table 1: Distribution of Dendrobium spp. across different districts of Tripura

\begin{tabular}{|c|c|c|c|c|c|c|c|c|c|c|c|c|c|}
\hline \multirow{3}{*}{ Sl. No. } & \multirow{3}{*}{ Species } & \multirow{2}{*}{\multicolumn{8}{|c|}{${ }^{* *}$ Name of the districts in Tripura }} & \multicolumn{3}{|c|}{ Altitudinal range (meter) } & \multirow{3}{*}{$\begin{array}{l}\text { IUCN } \\
\text { Status } \\
\end{array}$} \\
\hline & & & & & & & & & & Low & Medium & High & \\
\hline & & St & $\mathrm{Gm}$ & $\mathrm{Sj}$ & WT & $\mathrm{Kh}$ & $\mathrm{Dh}$ & Uk & $\mathrm{Nt}$ & $>200-300$ & $300-500$ & $\begin{array}{l}500- \\
800>\end{array}$ & \\
\hline 1 & DAPH & + & + & + & + & + & + & + & - & + & + & + & $\mathrm{L} \mathrm{C}$ \\
\hline 2 & DANG & - & + & - & - & + & - & - & + & - & - & + & NA \\
\hline 3 & DCHY & - & - & - & - & - & - & - & + & - & - & + & NA \\
\hline 4 & DDFM & - & - & - & - & - & - & - & + & - & - & + & NA \\
\hline 5 & DFMB & - & - & - & - & - & - & - & + & - & + & + & NA \\
\hline 6 & DFMS & - & - & - & - & - & - & - & + & - & + & + & NA \\
\hline 7 & DSLS & - & - & - & - & - & - & - & + & - & + & + & NA \\
\hline 8 & DTRS & - & - & - & - & - & - & - & + & - & - & + & NA \\
\hline 9 & DLYI & - & + & - & - & - & - & - & + & - & + & + & NA \\
\hline 10 & DCPS & - & - & - & - & - & - & - & + & - & - & + & NA \\
\hline
\end{tabular}

[**=synonym; + = present; - = absent, St=South Tripura, Gm=Gomati, Sj=Sipahijala, WT=West Tripura, Kh=Khowai, Dh=Dhalai, Uk=Unakoti, Nt=North Tripura, Lc= Least concern, NA= Not Assesed.]

Table 2: Flowering phenology of Dendrobium spp.

\begin{tabular}{|c|c|c|c|c|c|c|c|c|c|c|c|c|c|}
\hline \multirow{4}{*}{ No } & \multirow{4}{*}{ Species } & \multicolumn{12}{|c|}{ Season } \\
\hline & & \multirow{2}{*}{ Winter } & \multirow{2}{*}{\multicolumn{3}{|c|}{ Summer }} & \multicolumn{7}{|c|}{ Monsoon } & \multirow{3}{*}{$\begin{array}{l}\text { Win } \\
\text { Dec }\end{array}$} \\
\hline & & & & & & \multicolumn{2}{|c|}{ Pre Mon } & Ear & \multicolumn{2}{|c|}{ Mid } & \multicolumn{2}{|c|}{ Late } & \\
\hline & & Jan $\quad$ Feb & March & Apr & May1 & May2 & Jun1 & $\begin{array}{ll}\text { Jun2 } & \text { Jul }\end{array}$ & Aug & Sept & Oct & Nov & \\
\hline 1 & DAPH & & & & & & & & & & & & \\
\hline 2 & DANG & & & & & & & & & & & & \\
\hline 3 & DCHY & & & & & & & & & & & & \\
\hline 4 & DDFM & & & & & & & & & & & & \\
\hline 5 & DFMB & & & & & & & & & & & & \\
\hline 6 & DFMS & & & & & & & & & & & & \\
\hline 7 & DSLS & & & & & & & & & & & & \\
\hline 8 & DTRS & & & & & & & & & & & & \\
\hline 9 & DLYI & & & & & & & & & & & & \\
\hline 10 & DCPS & & & & & & & & & & & & \\
\hline
\end{tabular}

[Pre-Mon: Pre-monsoon, Ear: Early Monsoon, Mid: Mid-monsoon, Late: Late Monsoon, Win: Winter]

sun light condition at elevation ranges from 550 to $760 \mathrm{~m}$.

Specimen Examined: Tripura, North district, Jampui hill, vanghmun, $\pm 750 \mathrm{~m}, 23^{\circ} 59^{\prime} 33.6^{\prime \prime} \mathrm{N}$, 92¹6'35.9"E, 29-3-2017, Datta and Baishnab, 1963 (TUH).

6. Dendrobium salaccense (Blume) Lindl., Gen. Sp. Orchid. Pl.: 86. 1830. Grastidium salaccense Blume, Bijdr. Fl. Ned. Ind.: 333. 1825. Dendrobium cathcartii Hook.f., Fl. Brit. India 5: 727. 1890.

Epiphyte without pseudobulbs, stem erect bamboo cane like, round, branchless with many nodes and internodes. Leaves $10-15 \mathrm{~cm}$ long, occurs in two rows, linear-lanceolate, unequally 2 -fid at the apex. Flowers in leaf opposed pairs, $2.5 \mathrm{~cm}$ across, golden yellow with purple on the lip; dorsal sepal ovatelanceolate. Petals narrower. Mentum stout incurved, shorter than the lanceolate lateral sepals. Lip elliptic-oblong with a long tape like callus near apex. Column and anther cap yellow (Fig. 1).

Distribution: China, Myanmar, Thailand, Malaysia, Laos, Vietnam, Java, Borneo and Sumatra, India.
Phenology: Flowering and fruiting were observed from June to August.

Habitat and Ecology: Epiphyte, small to large sized, warm to cool growing epiphyte on tree trunk of Ficus species in mixed forest of Jampui hill.

Specimen Examined: India, Tripura, North district, Jampui hill, $\pm 750 \mathrm{~m}, 23^{\circ} 52^{\prime} 29.9^{\prime \prime N}, 92^{\circ} 16^{\prime} 04.3^{\prime \prime E}$, 097-2016, Datta and Baishnab, 1979 (TUH).

7. Dendrobium transparens Lindl. ex, Wall. ex Lindl., Gen. Sp. Orchid. Pl.: 79. 1830.

Hook.f., Fl. Brit. India 5: 738. 1890.

Epiphytes with pendulous stem. Leaves linear to lanceolate, acute, 7.5-10 cm long. Flower about $3.8-4 \mathrm{~cm}$ across, in pairs of leafless stem, flowers white and pink, bracts very large. Mentum conical, sepal's lanceolate, petals ovate. Lip with broad purple single blotch, elliptic, oblong, cuneate at the base, obtusely lobed, recurved, pubescent (Fig. 1).

Distribution: western Himalayas, Bangladesh, eastern Himalayas, (Assam, Tripura) India, Nepal, Bhutan, Sikkim, and Myanmar. 


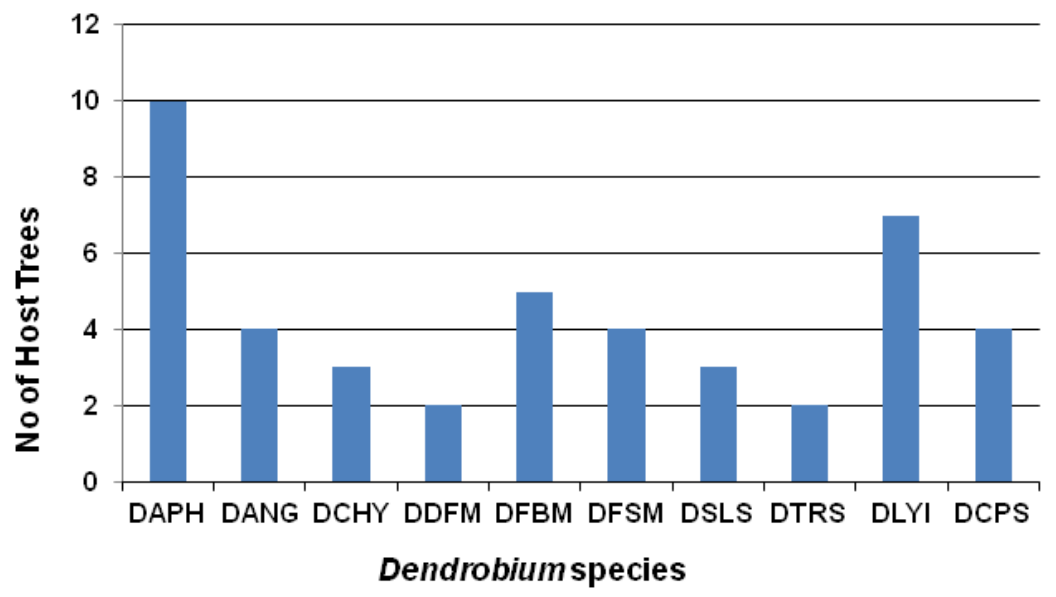

Fig. 5: Preference of host trees by Dendrobiums.

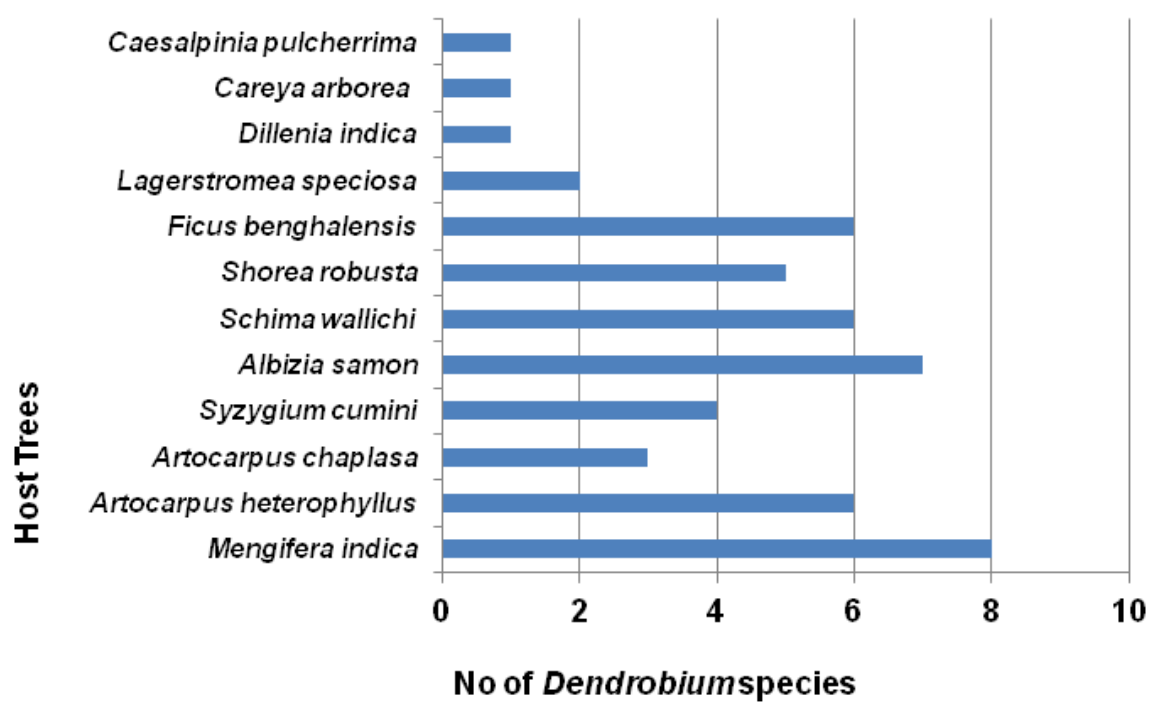

Fig. 6: Preference of Dendrobiums by host trees

Phenology: Flower and fruiting observed in April - July.

Habitat and Ecology: Medium to large sized, warm to cold growing epiphyte on tree trunks at shady forest.

Specimen Examined: India, Tripura, North district, Jampui hill, $\pm 599 \mathrm{~m}, 23^{\circ} 51^{\prime} 27.19 " \mathrm{~N}$, 92 16'7.72"E, 14-5-2018, Datta and Baishnab, 1968 (TUH).

8. Dendrobium capillipes Rchb.f., Gard. Chron. 1867: 997.1867. Callista capillipes (Rchb.f.) Kuntze, Revis. Gen. Pl. 2: 654. 1891.

Compact fusiform stems, $6-15 \mathrm{~cm}$, mature stem ca.1.5 cm in diameter, plump, branchless with few internodes. Leaves $2-4$, at the tip of stem, intently rhombus and regularly size is 10-12 × 1 $1.5 \mathrm{~cm}$, gristly, base sheathed, apex a little obtuse and diagonally emarginated. Inflorescences from leafless mature stems, $12-15 \mathrm{~cm}, 2$ to many flowered; rachis with 2 or 3 sheaths at bottom, thin; floral bracts light green, ovate, minute, apex sharp. Ovary and pedicel light green, 2 to $2.2 \mathrm{~cm}$. Flower $2 \mathrm{~cm}$ across, bright yellow, lip with red stripes, column yellow. Sepals equal in size ovate- lanceolate, broad at middle, apex acute. Petals ovate-elliptic, 4-veined, a little obtuse at apex; lip apex broad, ca. $20 \times 25 \mathrm{~mm}$, base cover column on both sides, margin ripple, apex notched. Column $4 \mathrm{~mm}$ in length; anthers two celled (Fig. 2).

Distribution: India, Nepal, Bhutan, Bangladesh, Myanmar, Thailand, Vietnam.

Phenology: Flowering and fruiting occurs in April - July.

Habitat and ecology: warm to cool budding epiphyte found at Jampui hill at elevations of 500 to 800 meters in moist, mixed deciduous forests.

Specimen Examined: India, Tripura, North district, Jampui hill (vanghmun), $\pm 657 \mathrm{~m}, 23^{\circ} 52^{\prime} 29.9^{\prime \prime N}$, 92¹6'4.3"E, 12-4-2018, Datta and Baishnab, 2068 (TUH).

9. Dendrobium formosum Roxb. ex Lindl., in N.Wallich, Pl. Asiat. Rar. 1: 34. 1830; Hook.f.,Fl. Brit. India 5: 721. 1890. Callista formosa (Roxb. ex Lindl.) Kuntze, Revis. Gen.Pl. 2: 654. 1891.

Stems thick and pointed upwards, inflated at the base, covered by leaf sheath, narrowed towards tip; 8 to $15 \mathrm{~cm}$ long and 1 to $2 \mathrm{~cm}$ in cross segment, 
Leaves sessile, oblong, opposite on both side of the pseudobulb, 2-2.9 $\times 0.5-0.9 \mathrm{~cm}$. Inflorescence at the tip of stem 3 to 4 flowered; peduncle sheathed, 4.3$4.5 \mathrm{~cm}$ long; floral bracts ovate, obtuse, 1.1-1.2 $\times$ $0.2-0.4 \mathrm{~cm}$. Flowers odorous, $5-9 \mathrm{~cm}$ in size, white, yellowish-orange spot present on lip; pedicel with ovary 3.5-5 cm long. Dorsal sepal linear to lanceolate, acute; lateral sepals quadrilateral, subacute and join at base to produce mentum, 0.8$1 \mathrm{~cm}$ long. Petals ovoid to obovoid, margins ripple. Lip 3-lobed, lanceolate to broadly obovate, base shortly clawed, 5.5-7.6 × 3.5-5 cm; lateral lobes small; midlobe indistinctly 2 lobed, emarginated. Column broad, $1.3-1.9 \mathrm{~cm} \times 0.6-1.1 \mathrm{~cm}$; foot tiny, 0.9-0.45-0.6 cm. Capsule ovoid, green in colour (Fig. 3).

Distribution: India, Nepal, Bhutan, Bangladesh, Myanmar, Thailand, Vietnam.

Phenology: Flowering period and fruiting session occurs in from April - May.

Habitat and Ecology: warm to cold rising small to medium sized medium sized epiphyte on tree trunk and branch of on the species of Lagerostroemia sp, Mangifera sp., Albizia saman of mixed forest of Jampui hill at elevation ranges from 520 to $750 \mathrm{~m}$.

Specimen Examined: India, Tripura, North district, Jampui hill, $\pm 730,23^{\circ} 58^{\prime} 36.0^{\prime \prime} \mathrm{N}$, 92¹6'44.5"E, 15-5-2017, Datta and Baishnab, 1970 (TUH).

10. Dendrobium aphyllum (Roxb.) C.E.C.Fisch, in Gamble, Fl. Press. Madras 3: 1416.1928. Limodorum aphyllum Roxb., Pl. Coromandel 1: 34. 1795. Dendrobium pierardii R. Br., Bot. Reg. 7: t. 548. 1821; Hook.f., Fl. Brit. India 5: 738. 1890.

Epiphyte with cane-like, clustered, 20-150 cm pendulous stem. Leaves 3-10 $\times 1-3 \mathrm{~cm}$ and become leafless before flowering. Short inflorescences come from sideways of the deciduous stems. Usually many inflorescences occur per plant including one to three flowers on each. Flower 4-5 $\mathrm{cm}$ across and bloom broadly with amusing smell. Sepals and petals are almost similar in length, sepal lanceolate and petals ovate in shape; sepal and petals rather lucent, creamy white, more or less stoutly covered and striking with pinkish violet. The lip is trumpet-shaped, 2.0-3.7 cm wide in spread, pale yellow and whitish at the base and covered with crowded, spongy, tiny hairs on the outer surface and along the borders, except in the basal part. Pedicel and ovary about $3 \mathrm{~cm}$ long, anterior part of the column is somewhat swollen occupied by stigma (Fig. 4).

Distribution: India, Nepal, Bhutan, Burma, China, Thailand, Cambodia, Vietnam, Malaysia.

Phenology: Flowering and fruiting were observed in April - June.
Habitat and Ecology: Epiphyte in mixed deciduous forest or open forest of road side, maximum on tree trunk of Albizia saman. This is one of the most common Dendrobium in Tripura growing at elevation ranges from 40 to $150 \mathrm{~m}$.

Specimen Examined: India, Tripura, Gomati District, Udaipur (Maharani), $\pm 41 \mathrm{~m}, 23^{\circ} 28^{\prime} 41.7^{\prime \prime} \mathrm{N}$, 9139'16.2"E, 12-04-2017, Datta and Baishnab, 1959 (TUH).

\section{Ecological Studies}

\section{Distribution of Dendrobium spp in Tripura}

Out of ten, nine species, $D$. angulatum (DANG), $D$. chrysotoxum (DCHY), D. densiflorum (DDFM), D. fimbriatum (DFMB), D. formosum (DFMS), $D$. salaccense (DSLS), D. transparens (DTRS), D. lindleyi (DLYI), D. capillipes (DCPS) of this genus distributed in North Tripura district at altitudinal range of Jampui hill. One species, D. aphyllum (DAPH) found throughout the state but less frequent in high altitude. $D$. lindleyi (DLYI) distributed in Jampui as well as in Dumbur of Gomati district. Maximum of them observed at medium to high altitudinal ranges (from 400 to 800> meter). D. aphyllum grows at all the altitudinal ranges (low to high) (Table 1).

\section{Flowering Phenology}

At the end of winter Dendrobium orchids started flowering in Tripura. According to their flowering session, Dendrobiums of Tripura have been considered into two phenological groups. $D$. aphyllum, $D$. angulatum, $D$. chrysotoxum, $D$. densiflorum, $D$. fimbriatum, $D$. formosum, $D$. salaccense, $D$. transparens, and $D$. lindleyi are summer orchids. Flower initiations of these orchids takes place at the entry of summer and are mentioned as summer orchids. Rest one $D$. capillipse falls under monsoon group and it blooms pre monsoon to early monsoon (Table 2).

\section{Host Preference}

D. aphyllum, D. lindleyi, D. fimbriatum grows on maximum number of host tree species where as other species were found on two or three host trees, namely, Mangifera indica, Artocarpus heterophyllus, Artocarpus chaplasa, Syzygium cumini, Albizia saman, Schima wallichi, Shorea robusta, Ficus benghalensis, Lagerstroemia speciosa, Dillenia indica, Careya arborea, Caesalpinia pulcherrima. Dendrobium species such as D. aphyllum mostly prefers Albizia saman, Careya arborea and Shorea robusta; $D$. lindleyi prefer Mangifera indica and Schima wallichi; $D$. fimbriatum - Ficus benghalensis, Lagerstroemia speciosa; D. salaccense - Ficus benghalensis; D. transparens - Careya arborea. Other five species $D$. angulatum, $D$. chrysotoxum, $D$. densiflorum, $D$. formosum, D. capillipse respectively found on Syzygium cumini, Dillenia indica, Artocarpus 
chaplasa, Albizia saman and Schima wallichi (Fig. 5 \& 6).

\section{Discussion}

The genus Dendrobium dominates the orchid flora of Tripura containing 10 species. In Tripura ten member of the genus distributed in different floristic and altitudinal ranges. Of them, new distributional records of three species are reported in the present study. Orchids of this genus mostly distributed in Jampui range of north Tripura at high altitude. In Tripura most of them blooms in summer. Most prefers host trees of the spp are Albizia saman, Mangifera indica, Ficus benghalensis, Schima wallichi. Dendrobiums are most attractive for their amazingly decorated flowers. But the matter is to conserve these orchids in natural habitats. It is now necessary to protect the valuable orchid species as they are very sensitive to ecological disturbance. Although there are 10 species of the genus Dendrobium exists in Tripura, their population is very poor and might be extinct in future. Most of the Dendrobium species like Dendrobium angulatum, Dendrobium formosum, Dendrobium salaccense and Dendrobium transparens are become locally rare and others are occasional. Habitat destruction, corrosion and deforestation, preface of exotic species, over-exploitation, environmental pollution, global warming and shifting cultivation are the main reasons for the decrease of population and species diversity of Dendrobium. For these, conservation of important Dendrobium orchid wealth in natural habitats through protection with modern methods of conservation like in vitro conservation, seed storage and cryopreservation.

\section{Acknowledgements}

This study was carried out during the project work "Orchid bioresources of the North- east India Conservation, database development and information networking” Sanction letter No. BCIL/ NER-BPMC/2016, funded by Department of Biotechnology, Ministry of Science and Technology, Government of India, New Delhi. Authors are thankful to Mr. Mantosh Roy, field assistant of this project for his helping hand.

\section{Competing Interests}

The authors confirmed that they have no competing interest.

\section{Author's Contribution}

The first author collected the orchids, identified them and analysed the field data and wrote the manuscript. The second author checks the paper, suggested the idea about the design of the manuscript and mentored the project.

\section{References}

1. De LC, Rao AN, Rajeevan PK, Srivastava M, Chhetri G. Morphological characterization in Dendrobium species. Journal of Global Biosciences, 2015;4(1):1198-1215.

2. Mabberley, DJ. Mabberley's Plant - Book; A portable dictionary of plants, their classification and uses. Cambridge University Press. $4^{\text {th }}$ Ed. Published in 2017; First South Asia Edition 2018. https://doi.org/10.1017/9781316335581

3. Karthikeyan S, Jain SK, Nayar MP, Sanjappa M. Florae Indicae Enumeratio; Monocotyledonae. Director, BSI, Howrah. 1989.

4. Singh KP, Phukan S, Bujarbarua P. Floristic Diversity and Conservation Strategies in India, Botanical Survey of India. 2001, 5: 1736-1764.

5. Deb DB, The Flora of Tripura State. Today and tomorrow's Printers and Publishers, New Delhi. 1983; 2.

6. Baishnab B, Banik B, Majumdar K, Datta BK. Four New Additions of Orchid Species for the Flora of Tripura, North East India. Envis Bulletin Himalayan Ecology, 2017; 25:111-115.

7. Jain SK, Rao RR. Handbook of field and herbarium methods. Goyal Offsets, Delhi. 1977

8. Chen X, Liu Z, Zhu G, Lang K, Ji Z, Luo Y, Jin X, Cribb PJ, Wood JJ, Gale SW, Ormerod P, Vermeulen JJ, Wood HP, Clayton D and Bell A. Orchidaceae, Flora of China, Science Press, Beijing; Missouri Botanical Garden Press, St. Louis, USA. 2009; vol. 25.

9. Chowdhery HJ. Orchid flora of Arunachal Pradesh. Botanical Survey of India, Calcutta. 1998.

10. Gogoi K, Das R, Rai S, Yonzone R. Orchids in Assam, India: The Genus Dendrobium Swartz. The Mios Journal 2014;15(8):5-24.

11. Hooker JD. Orchidaceae. In: Flora of British India. L. Reeve and Co., Ashford, Kent. 1890;5:687-864 \& 6:1198.

12. King G, R Pantling. The Orchids of the Sikkim Himalaya. Annals of the Royal Botanic Garden, Calcutta 1898;8:1-342

13. Lokho A. Diversity of Dendrobium Sw. Its Distributional Patterns and Present Status in the North-east India. International Journal of Scientific and Research Publications 2013;3(5):1-9

14. Lucksom SZ. The Orchids of Sikkim and North East Himalaya: Development Area, Jiwan Thing Marg, Gangtok, East Sikkim; 2007.

15. Misra S. Orchids of India. Bishen Singh Mahendra Pal Singh, Dehra Dun, India; 2007.

16. IUCN. The IUCN Red List of Threatened Species. Version 2. IUCN Red List Unit, Gland, Switzerland and Cambridge, UK, http://www.iucnredlist.org, 2018. 